\title{
Effects of Nitrogen and Phosphorus Fertilizers on Dekoko (Pisum sativum var.abyssinicum A. Braun) Yield and Yield related traits
}

\author{
Kiros Wolday ${ }^{1}$, Araya Alemie ${ }^{2} \&$ Yemane Tsehaye $^{2}$ \\ ${ }^{1}$ Crop Research core process,Axum Agricultural Research Center, Ethiopia \\ ${ }^{2}$ Department of Crop and Horticultural Science, Mekelle University, Ethiopia \\ Correspondence: Kiros Wolday, Crop Research core process,Axum Agricultural Research Center, Ethiopia. Tel: \\ 251-925-425-358. E-mail: kiroswolday@gmail.com
}

Received: June 7, 2020 Accepted: June 27, 2020 Online Published: August 11, 2020

\begin{abstract}
A field experiment was conducted to investigate the influence of different nitrogen and phosphorus fertilizer levels on dekoko (Pisum sativum var.abyssinicum A.Braun) yield and yield components as well as to establish the net benefit at each fertilizer levels. The Experiment was conducted at Mekelle university Endayesus campus in Tigray, Northern Ethiopia in 2013/14. It was laid out in a randomized complete block design with four blocks. It comprises four nitrogen $(\mathrm{N})$ and phosphorus (P) fertilizer treatments combinations. Viz., Control (N0P0), $30 \mathrm{~kg} \mathrm{~N}^{-1}$ and $30 \mathrm{~kg} \mathrm{P}_{2} \mathrm{O}_{5} \mathrm{ha}^{-1}$ (N1P1), $60 \mathrm{~kg} \mathrm{~N} \mathrm{ha}^{-1}$ and $60 \mathrm{~kg} \mathrm{P}_{2} \mathrm{O}_{5} \mathrm{ha}^{-1}(\mathrm{~N} 2 \mathrm{P} 2)$ and $90 \mathrm{~kg} \mathrm{~N} \mathrm{ha}^{-1}$ and $90 \mathrm{~kg} \mathrm{P}_{2} \mathrm{O}_{5} \mathrm{ha}^{-1}$ (N3P3).The highest yield $\left(2114.55 \mathrm{~kg} \mathrm{ha}^{-1}\right)$, biomass $\left(5312.5 \mathrm{~kg} \mathrm{ha}^{-1}\right)$, nitrogen and phosphorus use efficiency $(4.58 \mathrm{~kg} \mathrm{kg-1})$ and maximum marginal rate of return $(499 \%)$ were obtained when treated with N2P2. From the present results it could be concluded that $60 \mathrm{~kg} \mathrm{~N} \mathrm{ha}^{-1}$ and $60 \mathrm{~kg} \mathrm{P}_{2} \mathrm{O}_{5} \mathrm{ha}^{-1}$ fertilizer rate would be optimum treatment combination for enhancing dekoko yield and yield components, NP use efficiency, and economic profitability. Therefore, application of $60 \mathrm{~kg} \mathrm{~N} \mathrm{ha}^{-1}$ and $60 \mathrm{~kg} \mathrm{P}_{2} \mathrm{O}_{5} \mathrm{ha}^{-1}$ is recommended for better productivity and profitability of dekoko at low soil fertility levels.
\end{abstract}

Keywords: Dekoko, marginal rate of return, nitrogen and phosphorus fertilization, yield

\section{Introduction}

Grain legumes, play a key role in organic cropping systems (Aslamet al., 2010). They could provide nitrogen (N) to the system via $\mathrm{N}$ fixation and produce grain rich in protein while improving soil $\mathrm{N}$ for the succeeding crop (Newton and Yoong, 2015).

In Ethiopia, dekoko is known for its high market price and for its food preference (Yemane and Skjelva ${ }^{\circ} \mathrm{g}, 2002$ ). It is well known for its good taste and high nutritional value. Most often, the dry seeds of dekoko are decorticated and split ('split peas') before boiling. Sometimes they are boiled without decortications and consumed as soup. In Ethiopia the annual consumption per person of field pea including dekoko seeds is estimated at $6-7 \mathrm{~kg} / \mathrm{year}$ (Sentayehu,2009). Dekokois importantbecause of its favorable amino acid profile;it can be a suitable complementary protein source for a cereal based diet (Yemane and Skjelva ${ }^{\circ} \mathrm{g}, 2002$ ). Moreover, its early maturation can make it an important crop in areas where the growing season is too short for other cool season food legumes (CSFLs) and yield losses caused by terminal droughts are common.In Areas where crop yields are mainly water- limited under dryland production systems in semi arid regions.

Despite its high nutritional and economic value, dekoko is the most neglected pulse crop in the research area. Hence, its productivity is low because of lack of improved varieties, low soil fertility; little or no application of fertilizers or fertilizer requirement of the crop is not well known. Dekoko is usually sown without fertilizer and as a result its yield under farmer's condition is often below optimum. Nitrogen and phosphorus are the essential nutrients for dekoko growth and to improve its productivity. Nitrogen promotes the vegetative development of the crop where as phosphorus plays a vital role in root development, nitrofen fixation, maturity and energy transfer processThere is limited information about the effect of nitrogen and phosphorus fertilization on dekoko yield, NP use efficiency and economic profitability. It was hypothesized that supplying optimum amount of $\mathrm{N}_{\text {and }} \mathrm{P}_{2} \mathrm{O}_{5}$ in dekoko fields could improve its productivity and profitability. 


\section{Materials and Methods}

\subsection{Description of the Study Area}

The study was carried out at Mekelle University Endayesus campus research site in Tigray region, Northern Ethiopia in 2013/14 growing season. The area is located at a geographical location of latitude $13^{\circ} 28^{\prime} 47^{\prime} ' \mathrm{~N}$ and longitude $39^{\circ} 29^{\prime} 10^{\prime \prime} \mathrm{E}$ and at an altitude of 2225 meter above sea level (m.a.s.l).

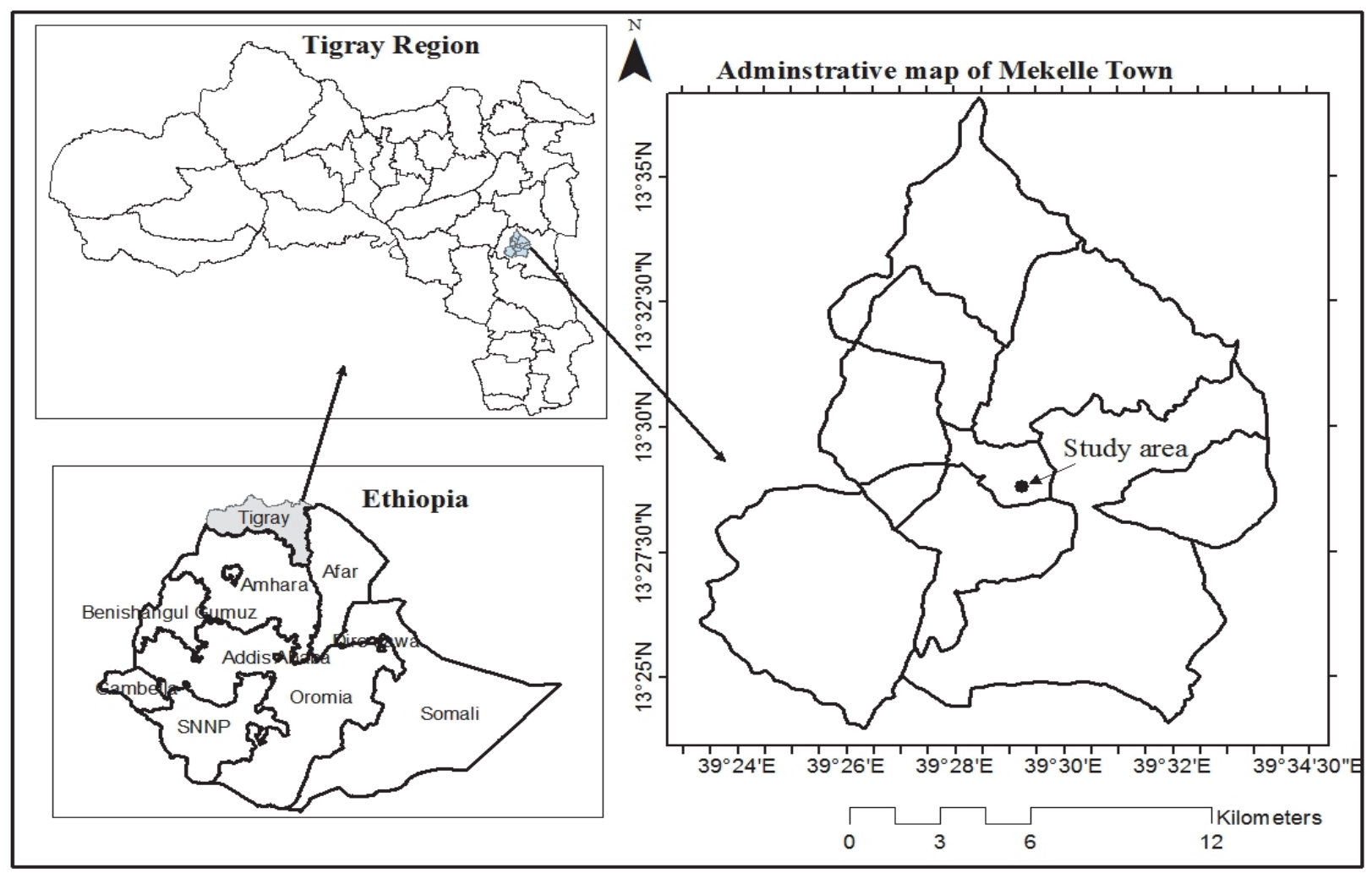

Figure 1. Location map of the study area

Climatologically the area is categorized as semi arid. Rainfall distribution of the study area is largely mono-modal that spreads from June to first week of September. The long term (1993 -2013) mean annual rainfall for the study site is approximately $543 \mathrm{~mm}$. The highest rainfall is received in July and August and the mean annual average maximum and minimum temperature of the study area approximately, $26.2^{\circ} \mathrm{C}$ and $11.5^{\circ} \mathrm{C}$ respectively.

The dominant soil type of the experimental site is a Cambisol (Habtegebrial and Singh, 2006). It has sandy clay loam (53\% sand, $27 \%$ silt and $20 \%$ clay). The soil $\mathrm{pH}$, cation exchange capacity (CEC), available phosphorus, and total nitrogen were $6.9,19.75 \mathrm{cmol} \mathrm{kg}^{-1}, 2.75 \mathrm{mg} \mathrm{kg}^{-1}$ and $0.1 \%$ respectively. The percent organic carbon content of the soil was $1.15 \%$. the organic carbon of the soil is computed by multiplying the organic carbon content with conversion factor of 1.724 , and the organic matter of the soil was $1.98 \%$.

\subsection{Treatments, Experimental Design and Procedures}

The experiment consisted of four treatment combinations: Control (NOP0), $30 \mathrm{~kg} \mathrm{~N} h a^{-1}$ and $30 \mathrm{~kg} \mathrm{P}_{2} \mathrm{O}_{5} \mathrm{ha}^{-1}$

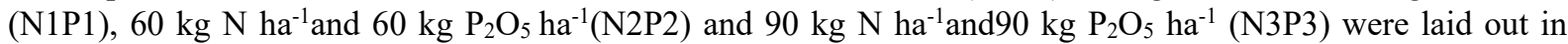
randomized complete block design (RCBD) and replicated four times andeach treatment was randomly assigned to each plots. Dekoko Seeds for planting were obtained from farmers living in korem (163km South of Mekelle). The plots had an area size of $4 \mathrm{~m} \times 4 \mathrm{~m}$ with harvestable area of $2 \mathrm{~m} \times 2 \mathrm{~m}$ and $1 \mathrm{~m}$ between plots and $1.5 \mathrm{~m}$ between replications. Inter and intra row spacing was $0.2 \mathrm{~m}$ and $0.05 \mathrm{~m}$, respectively. Two seeds where planted per hill. After emergence plants where thinned to one seed to maintain normal plant density. Fertilizer Sources for phosphorus was DAP (Di-ammonium phosphate) and urea for Nitrogen-ammonium phosphate was applied at sowing whereas; urea was applied after $100 \%$ crop emergence. 


\subsection{Data Collection}

Data were collected on plant and plot basis. The collected data are listed as follows:

Days to $50 \%$ flowering and maturity were recorded as number of days from planting up to the time when $50 \%$ of the plants in each plot flowered and matured, respectively. Plant height was recorded from five individual plants by measuring the length from the ground to the apex of the plant during maturity stage; pod length was assumed as the average pod length of the total pods from five plants; number of pods per plant were recorded from five plants randomly taken from the central(harvestable) rows by counting all grain filled pods on each plant; number of seeds per pod were recorded from five randomly selected plants by dividing to the total number of pods counted from the five randomly selected plants;aboveground biomass weight per plot was taken as the total aboveground biological yield from the harvestable plot area $\left(4 \mathrm{~m}^{2}\right)$ and weighed after sun drying for a week; grain yield per plot was recorded by separating the grains from the straw after threshing; thousand grain weight was estimated by counting and weighing 1000 seeds from each harvestable plot area. Finally harvest index was estimated as the ratio of grain yield to the total aboveground biological yield.

\subsection{Partial Budget Analysis}

Partial budget analysis was worked out to determine the most economically accepted treatments by estimating the varying costs and benefits depending on the prevailing market prices (CIMMYT,1988). The yields harvested from the experimental plots were converted in to hectare basis and the market values were calculated by multiplying the existing market price with grain yield obtained per hectare.

Net benefits for each treatment were calculated by subtracting the variable costs from the gross income. And the marginal rate of return was calculated by comparing the marginal (extra) cost with the marginal net benefit. Because higher net benefit may not be accepted if they are attained at higher costs.

Gross and net benefits were determined according to CIMMYT (1988). Gross benefit (GB) $=$ Yield * price, Net benefit $(\mathrm{NB})=$ Gross Benefit $(\mathrm{GB})$ - varying cost $(\mathrm{VC})$. This analysis helps to undertake the marginal rate of return (MRR) analysis which is important for correct evaluation of alternative technologies. Cost that varies between treatments (cost of $\mathrm{N}$ and $\mathrm{P}_{2} \mathrm{O}_{5}$ fertilizer) was used in the calculation of partial budget analysis.

Marginal analysis was calculated by using the net benefit and variable cost values. Final recommendations to farmers were given on the basis of marginal rate of return, which was calculated by the following formula (CIMMYT, 1988).

$$
\text { Marginal rate of return }(\%)=\frac{\text { Marginal net benefit }}{\text { Marginal variable cost }} * 100
$$

\subsection{Data Analysis}

Plots of the distribution of the residuals, a normal and half-normal plots and a plot of the residuals against the fitted values were produced to assess whether the normality assumptions of the data was violated. All the parameters measured were statistically analyzed using Analysis of variance (ANOVA) function of statistical analysis system (SAS Institute, 2002). The least significance difference (LSD at a probability level of 5\%) test was used to separate the treatment mean value after treatment effect was found significant at $\mathrm{P} \leq 0.05$. Moreover, simple correlation analysis was worked out to reveal the magnitudes and directions of relationships between selected yield and yield components.

\section{Results and Discussion}

\subsection{Effect of $\mathrm{N}$ and $\mathrm{P}_{2} \mathrm{O}_{5}$ on Dekoko Phenology, Yield and Yield Components}

Analysis of variance on $50 \%$ flowering exhibited a significant difference among treatments of $\mathrm{N}$ and $\mathrm{P}_{2} \mathrm{O}_{5}$ fertilizer treatments compared to the control at $(\mathrm{P} \leq 0.05)$ (Table 1).The plants received the highest fertilizer level (N3P3) took longer days to $50 \%$ flowering (41 days) as compared to the control (40.25 days). Whereas, early flowering was observed on the control treatment (40.25 days). As $\mathrm{N}$ and $\mathrm{P}_{2} \mathrm{O}_{5}$ level increased from 0 to $90 \mathrm{~kg} \mathrm{~N} \mathrm{ha}^{-1}$, the days to $50 \%$ flowering was delayed. Increasing $\mathrm{N}$ fertilizer level promoted greater vegetative development for a longer period of time before reproductive phase begins and hence, might have caused delayed in flowering (Achakzai, 2012).

Results presented in Table1 revealed that there was a non-significant variation among various levels of added $\mathrm{N}$ and $\mathrm{P}_{2} \mathrm{O}_{5}$ fertilizers, as indicated in Table 1, however, the clear and significant variation was between the high level of $\mathrm{N}$ and $\mathrm{P}_{2} \mathrm{O}_{5}$ and the untreated control. Days to maturity followed the same trend as that of the days to flowering; 
as the $\mathrm{N}$ and $\mathrm{P}_{2} \mathrm{O}_{5}$ rate increases maturity tend to delay (Table 1). The increase in $\mathrm{N}$ level could increased the vegetative growth of the crop as a result crop maturity tend to delayed.

Days to maturity followed the same trend like the days to flowering by the application of various levels of $\mathrm{N}$ and $\mathrm{P}_{2} \mathrm{O}_{5}$ (Table 1). This might be attributed to the specifically higher levels of nitrogen fertilizer application which increases the vegetative growth of crops and hence delayed maturity. Rahim et al. (2008) observed significant variation in days to $50 \%$ maturity by the application of various levels of nitrogen fertilizers in mung bean. Similarly Khanet al. (2008) reported that crop maturity delayed by application of $\mathrm{N}$ fertilizer.

$\mathrm{N}$ and $\mathrm{P}_{2} \mathrm{O}_{5}$ fertilizer combination level had a significant effect on pod length at $\mathrm{P} \leq 0.05$. Increasing of $\mathrm{N}$ and $\mathrm{P}_{2} \mathrm{O}_{5}$ fertilizer from N0P0 to N3P3 increased pod length in a linear fashion. The linear trend between pod length and fertilizer rate observed in this study may further proved that nitrogen is the essential component for growth of the crop. The maximum pod length $(4.7 \mathrm{~cm})$ was recorded in N3P3 followed by N2P2 $(4.53 \mathrm{~cm})$. However, both treatments were statistically alike. Increasing the $\mathrm{N}$ and $\mathrm{P}_{2} \mathrm{O}_{5}$ rate beyond $\mathrm{N} 2 \mathrm{P} 2$ had no significant effect on pod length (Table 1). This indicates N2P2 could be the optimum fertilizer level, which should be applied for dekoko.

Table 1. Yield and yield components of dekoko as influenced by the combined application of $\mathrm{N}$ and $\mathrm{P} 2 \mathrm{O} 5$ fertilizer levels

\begin{tabular}{|c|c|c|c|c|c|c|c|c|c|}
\hline $\mathrm{N}+\mathrm{P}_{2} \mathrm{O}_{5}\left(\mathrm{Kg} \mathrm{ha}^{-1}\right)$ & $\begin{array}{l}50 \% \\
\text { DTF }\end{array}$ & $50 \%$ DTM & PL (cm) & NPPP & NSPP & $\begin{array}{l}\text { ABYLD (kg ha- } \\
\left.{ }^{1}\right)\end{array}$ & $\begin{array}{l}\text { GY } \\
\left(\mathrm{Kg} \mathrm{ha}^{1}\right)\end{array}$ & $\operatorname{TSW}(\mathrm{g})$ & HI (\%) \\
\hline 0(NOP0) & $40.25^{b}$ & $65.5^{\mathrm{b}}$ & $3.83^{\mathrm{b}}$ & $4.20^{\mathrm{c}}$ & $3.78^{b}$ & $4037.50^{b}$ & $1565.50^{\mathrm{b}}$ & $91.83^{b}$ & 38.58 \\
\hline $30+30(\mathrm{~N} 1 \mathrm{P} 1)$ & $40.75^{\mathrm{ab}}$ & $65.75^{\mathrm{ab}}$ & $3.87^{b}$ & $4.85^{\mathrm{b}}$ & $4.43^{\mathrm{b}}$ & $4550.00^{\mathrm{b}}$ & $1736.80^{\mathrm{b}}$ & $95.68^{\mathrm{b}}$ & 38.1 \\
\hline $60+60(\mathrm{~N} 2 \mathrm{P} 2)$ & $40.75^{\mathrm{ab}}$ & $65.5^{\mathrm{ab}}$ & $4.53^{\mathrm{a}}$ & $5.49^{\mathrm{a}}$ & $5.38^{\mathrm{a}}$ & $5312.50^{\mathrm{a}}$ & $2114.50^{\mathrm{a}}$ & $106.76^{\mathrm{a}}$ & 39.8 \\
\hline $90+90(\mathrm{~N} 3 \mathrm{P} 3)$ & $41.00^{\mathrm{a}}$ & $66.75^{\mathrm{a}}$ & $4.7^{\mathrm{a}}$ & $5.75^{\mathrm{a}}$ & $6.00^{\mathrm{a}}$ & $5750.00^{\mathrm{a}}$ & $2145.00^{\mathrm{a}}$ & $105.85^{\mathrm{a}}$ & 39.88 \\
\hline CV (\%) & 1.024 & 1.22 & 6.5 & 7.63 & 8.42 & 9.6 & 10.86 & 3.75 & 7.19 \\
\hline $\operatorname{LSD}(5 \%)$ & 0.67 & 1.12 & 0.45 & 0.62 & 0.66 & 754.05 & 331.99 & 5.99 & NS \\
\hline
\end{tabular}

Where: DTF=days to flowering, $\mathrm{DTM}=$ days to maturity, $\mathrm{PL}=$ Pod length, $\mathrm{NPPP}=$ number of pods per plant, $\mathrm{NSPP}=$ number of seeds per pod, $\mathrm{ABYLD}=$ Aboveground Biomass yield, $\mathrm{GY}=$ Grain yield, $\mathrm{HI}=$ Harvest index, TSW $=$ Thousand seed weight

**Means with different letters in each group are statistically significant at $\mathrm{P} \leq 5 \%$ (LSD), NS- not significant.

Application of $\mathrm{N}$ and $\mathrm{P}_{2} \mathrm{O}_{5}$ significantly affected the number of pods per plant $(P \leq 0.05)$ at all levels except in N1P1 when compared with the control (Table 1). The maximum number of Pods per plant was recorded from the application of high levels of N3P3 followed by N2P2, whereas, the lowest number of pods per plant attributed to the control (Table 1). This increased number of pods per plant with an increase in fertilizer level (apart from the fertilizer effect) may also emanate from the increase in number ofbranches. The result agrees with the finding of Rajpal (2003) who reported an increase in number of pods per plant with increasing level of phosphorus up to 60 $\mathrm{kg} \mathrm{P}_{2} \mathrm{O}_{5} \mathrm{ha}^{-1}$. Ahmed (200) also reported increase in number of pods per plant linearly with increase P2O5 up to $75 \mathrm{~kg} \mathrm{ha}^{-1}$. It could be an increase in the number of branches per plant could increase the number of reproductive nodes and then number of pods/plant might be increased.

The effect of $\mathrm{N}$ and $\mathrm{P}_{2} \mathrm{O}_{5}$ on the number of seeds per pod was significant $(\mathrm{p} \leq 0.05)$ (Table 1). The mean values of the treatments except at N1P1 were significantly higher than the control. The highest number of pods were recorded from the treatment combination of N3P3 followed N2P2 (Table 1). However, the mean values of the latter two treatments were not statistically different to each other.

There was a significant variation among the treatments of $\mathrm{N}$ and $\mathrm{P}_{2} \mathrm{O}_{5}$ fertilizer levels for above ground biomass compared to the control treatment (Table 1). With increasing the $\mathrm{N}$ and $\mathrm{P}_{2} \mathrm{O}_{5}$ fertilizer level, the above ground biomass appeared to increase linearly. However, the mean values of N2P2 and N3P3 were not statistically different from each other and the yield increment beyond (N2P2) was not that significant.

The low availability of $\mathrm{N}$ and $\mathrm{P}_{2} \mathrm{O}_{5}$ nutrients in the soil and application of $\mathrm{N}$ and $\mathrm{P}_{2} \mathrm{O}_{5}$ from the external inputs below N1P1, may be inadequate for the optimum growth and development of dekokoas can be noticed from the low aboveground biomass in N1P1 (Table 1).The non-significant difference between the higher levels of fertilizer combinations could be due to the adequate $\mathrm{N}$ and Fertilizer level for dekoko growth and development from the 
external input (N2P2). The increase aboveground mass could be the supply of nitrogen with phosphorus and other soil minerals which causes for the high vegetative growth of dekoko. This result is in acordance with the report of Masresha et al. (2016). The results are also in line with those of Fatima et al. (2013) who reported $\mathrm{N}$ and $\mathrm{P}_{2} \mathrm{O}_{5}$ combination showed significantly highest growth and yield contributing character.

The analysis of variance showed that grain yield was significantly affected by the combined application of the different nitrogen and phosphorus fertilizers levels at $(\mathrm{p} \leq 0.05)$. Nitrogen and Phosphorus application at all levels except at N1P1 brought significantly higher grain yield than the control (Table 1). It is evident from the result that the highest grain yield was recorded from the application of the higher fertilizer level. However, no significant variations were observed between $\mathrm{N} 2 \mathrm{P} 2$ and $\mathrm{N} 3 \mathrm{P} 3$. The lowest grain yield was recorded from the control treatment, where no fertilizer was applied. At lower levels, the nutrients were not available to plants in sufficient quantities which ultimately resulted in lower yield. The increase in grain yield of dekoko with increasing fertility level was mainly due to significant improvement in different growth and yield contributing characters at higher Nitrogen and phosphorus level. Application of higher quantity of Nitrogen might have favored rapid growth and enlargement of tissues, resulting in higher leaf area index. In addition to this application of phosphorus may increase the availability of $\mathrm{P}$ to plants leading to higher contents of $\mathrm{P}$ in grains. The increase in grain yield with increasing $\mathrm{N}$ and $\mathrm{P}_{2} \mathrm{O}_{5}$ Fertilizer levels may be due to the increase in number of branches/plant number of pods/plant, number of seeds/pod and pods/plant. Similar findings have been reported by Bolland et al. (2001) for various legumes.

Nitrogen along with phosphorus fertilizers significantly affected 1000 grain weight $(\mathrm{P} \leq 0.05)$ (Table 1$)$. The analysis of variance showed that with increasing the combined application of $\mathrm{N}$ and $\mathrm{P}_{2} \mathrm{O}_{5}$ appeared to increase the 1000 seed weight up to the application of N2P2 (Table 1). Maximum 1000 grain weight i.e., $106.68 \mathrm{~g}$ was recorded in plots received $\mathrm{N} 2 \mathrm{P} 2$ followed by N3P3 (105.85g), although the two treatment means were not significantly different from each other. The minimum seed weight was observed in the control treatment $(91.83 \mathrm{~g})$. However, beyond N2P2, the seed weight slightly declined. The most likely reason for having higher seed weight with an increase in $\mathrm{N}$ and $\mathrm{P}_{2} \mathrm{O}_{5}$ rate was attributed to better crop development and better NP uptake. Similar result was reported by Arif et al. (2003) and Sadozai et al. (2013).

None of the treatments had any significant effect on harvest index (HI) (Table 1). But the highest HI was obtained at the highest fertilizer levels (N2P2 and N3P3). Nevertheless, the treatment means were not statistically different from each other and this could be likely due to simultaneous increase in biomass resulted from an increase in $\mathrm{N}$ and $\mathrm{P}_{2} \mathrm{O}_{5}$ application. In line with current findings, Meseret (2006) and Gifole et al. (2011) have also reported nonsignificant response of harvest index to $\mathrm{P}$ application on mung bean and haricot bean respectively.

\subsection{Partial Budget Analysis of the Combined Application of $\mathrm{N}$ and $\mathrm{P}_{2} \mathrm{O}_{5}$}

Increasing the amount of $\mathrm{N}$ and $\mathrm{P}_{2} \mathrm{O}_{5}$ from N0P0 to N1P1 and N2P2 lead to an increment in net benefits beyond which further increment in the amount of $\mathrm{N}$ and $\mathrm{P}_{2} \mathrm{O}_{5}$ resulted in decline the net benefits. The marginal rate of return (MRR) from N0P0 to N1P1 and N2P2 were 170 and 499\%respectively. Partial budget analysis on the N and $\mathrm{P}_{2} \mathrm{O}_{5}$ fertilizer applied indicated that the treatment $\mathrm{N} 2 \mathrm{P} 2$ was the most economical with the highest marginal rate of return (MRR) followed by the N1P1. On the contrary further increase in $\mathrm{N}$ and $\mathrm{P}_{2} \mathrm{O}_{5}$ beyond N2P2 was dominated due to less benefit than the preceding treatment. Application of N3P3 gave marginal net benefit -800.69 (Table 2).

Table 2. Effect of $\mathrm{N}$ and P2O5 combined application on dekoko grain yield Marginal rate of return

\begin{tabular}{crrccc}
\hline $\begin{array}{c}\text { (N+P2O5) } \\
\mathrm{kg} \mathrm{ha}^{-1}\end{array}$ & VCIO & MVC & NB (Et.Birr) & MNB (ET.Birr) & MRR (\%) \\
\hline 0 (N0P0) & - & - & 35225 & - & - \\
$30+30(\mathrm{~N} 1 \mathrm{P} 1)$ & 1424.58 & 1424.58 & 37650.42 & 2425.42 & 170 \\
$60+60(\mathrm{~N} 2 \mathrm{P} 2)$ & 2852.78 & 1428.2 & 44772.22 & 7121.8 & 499 \\
$90+90(\mathrm{~N} 3 \mathrm{P} 3$ & 4278.47 & 1425.69 & $43971.53 \mathrm{D}$ & -800.69 & - \\
\hline
\end{tabular}

$\mathrm{D}=$ dominated treatment (due to less benefits than preceding treatments)

$\mathrm{VCIO}=$ Variable cost in increasing order, $\mathrm{MVC}=$ Marginal variable cost $=$ Net benefit, $\mathrm{MNB}=$ Marginal net benefit, $\mathrm{MRR}=$ Marginal rate of return, ET=Ethiopia 


\section{Conclusion}

The effect of nitrogen and phosphorus were statistically significant for most of the measured attributes, yield and yield components of dekoko (Pisum sativum var.abyssinicum A. Braun). Application of $60 \mathrm{~kg} \mathrm{~N} \mathrm{ha}^{-1}$ and $60 \mathrm{~kg}$ $\mathrm{P}_{2} \mathrm{O}_{5}$ ha-1 was found to be the suitable treatment combination level among the deferent levels of $\mathrm{N}^{-1}$ and $\mathrm{P}_{2} \mathrm{O}_{5}$ fertilizers, for enhancing dekoko yield and yield components. and also gave maximum marginal rate of return as compared to the other $\mathrm{N}$ and $\mathrm{P}_{2} \mathrm{O}_{5}$ levels of fertilizer, which indicates increasing application of nitrogen and phosphorus fertilizer beyond $60 \mathrm{~kg} \mathrm{~N} \mathrm{ha}^{-1}$ and $60 \mathrm{~kg} \mathrm{P}_{2} \mathrm{O}_{5}$ ha $^{-1}$ may not be a sound strategy to achieve maximum yield of dekoko. Therefore, based on the present finding, it is recommended that application of $60 \mathrm{~kg} \mathrm{~N} \mathrm{ha}^{-1}$ and $60 \mathrm{~kg} \mathrm{P}_{2} \mathrm{O}_{5}$ ha $^{-1}$ (N2P2) would be the optimum rate for increasing yield and better profitability of dekoko at low soil fertility levels. Furthermore, the results will applicable to areas possessing similar agro ecologies and similar soil fertility status. Further study should be conducted to analyze the main (separate) effect of $\mathrm{N}$ and $\mathrm{P}_{2} \mathrm{O}_{5}$ on dekoko yield and yield traits.

\section{Conflict of interest}

The authors have not declared any conflict of interest.

\section{Acknowledgements}

we sincerely thank Rockfeller foundation for the finacial support of this project

\section{References}

Achakzai, A. K., Shah, B. H., \& Wahid, M. A. (2012). Effect of nitrogen fertilizer on the growth of mungbean [vigna radiata (1.) wilczek] grown in quetta. pak. j. bot., 44(3), 981-987.

Ahmed, I. (2001). Effect of row spacing and phosphorus level on growth, yield and quality of mung bean, p.94.

Arif, M., Kakar, K. M., \& Kakar, G. M. (2003). Response of sunflower to various levels of nitrogen and phosphorous. J. Sci. Tech., Univ. Peshawar, 27, 63-66.

Aslam, M., Hussain, N., Zubair, M., Hussain, S. B., \& Baloch, M. S. (2010). Integration of organic \& inorganic sources of phosphorus for increased productivity of mungbean (Vignaradiata). Pak. J. Agri. Sci., 47, 111-115.

Bolland, D. A., Riethmuller, H. M., \& Loss, S. P. (2001). Methods of phosphorus application and row spacing on grain yield of Faba bean (Viciafaba L.). Aust. J. Exp. Agric., 41, 227-234. https://doi.org/10.1071/EA00057

CIMMYT. (1988). From agronomic data to farmer's recommendation: An Economics Training Manual, CIMMYT, Mexico.

Fatima, K., Hussain, N., Pir, F., \& Mehdi, M. (2013). Effect of nitrogen and phosphorus on growth and yield of Lentil (Lens culnaris). Elixir Int. J., 57, 14323-14325.

Gifole, G., Sheleme, B., \& Walelign, W. (2011). The Response of Haricot Bean (Phaseolus vulgaris L.) to Phosphorus Application on Ultisols at Areka, Southern Ethiopia. Journal of Biology, Agriculture and Health care, 1(3), 38-49.

Habtegebrial, K., \& Singh, B. R. (2006). Effects of timing nitrogen and sulphur fertilizers on yield, nitrogen, and sulphur contents of tef (Eragrostistef (Zucc.)Trotter). Nutr. Cycl. Agroecosyt, 75, 213-222. https://doi.org/10.1007/s10705-006-9028-8

Khan, F. S., Ahmed, Z. I., Ansari, M., \& Shah, H. (2008). Response of mungbean genotypes to Rhizobium inoculums and varying level of nitrogen fertilizer. Pak. J. Agric. Res., 21(1-4), 33-44.

Masresha, A. T., \& Kibebew, K. (2017). Effects of Rhizobium, Nitrogen and Phosphorus Fertilizers on Growth, Nodulation, Yield and YieldAttributes of Soybean at PaweNorthwestern Ethiopia. World Science News, 67(2), 201-208.

Meseret, F. (2006). Effect of population density, inter-row spacing and phosphorus fertilizer on yield and yield components of mung bean (Vignaradiata L.) wilczekatAwassa Research Center", M.Sc. Thesis, University of Hawasa, Awassa college of Agriculture, Ethiopia.

Newton, Z. L., \& Yoong, K. S. (2015). Carbon and Nitrogen Release from Legume Crop Residues for Three Subsequent Crops. American Journal of Soil Science Society, 79(6), 1650. https://doi.org/10.2136/sssaj 2015.05.0198

Rahim, M. A., Mia, A.A., Mahmud, F., \& Afrin, K. S. (2008). Analysis in some mungbean (VignaradiataL. Wilczek) accessions on the basis of agronomic traits. American J. Sci. Res., 3(2), 17-221. 
Rajpal, N. L. (2003). Effect of phosphorus and bio fertilizers on yield and yield attributes of cluster bean.Annals Agric. Res., 24(1), 145-147.

Sadozai, G. U., Farhad, M., Khan, A., \& Khan, E. A. (2013). Effect of Different Phosphorous Levels on Growth, Yield and Quality of Spring Planted Sunflower. Pak. J. Nutr., 12(12), 1070-1074. https://doi.org/10.3923/pjn.2013.1070.1074

SAS. (2002). Statistical analysis system (SAS) Institute Inc., SAS Campus Drive. Cary, NC, U.S.A.

Sentayehu, A. (2009). Assessment of Nutrient Contents of Different Field Pea Genotypes (Pisium sativum L.) in Southwest Ethiopia.Department of Plant Sciences, Jima University, Jimma, Ethiopia.

Toğay, Y., Toğay, N., Doğan.Y., \& Çiftçi, V. (2005). Effects of nitrogen level and forms on the yield and yield components.

Yemane, A., \& Skjelva ${ }^{\circ}$, A. O. (2002). The physic-chemical features of Dekoko (Pisumsativum var. abyssinicum) seeds. J. Agron and Crop Sci., 189, 14-22. https://doi.org/10.1046/j.1439-037X.2003.00595.x

\section{Appendix}

Weather condition of the study area

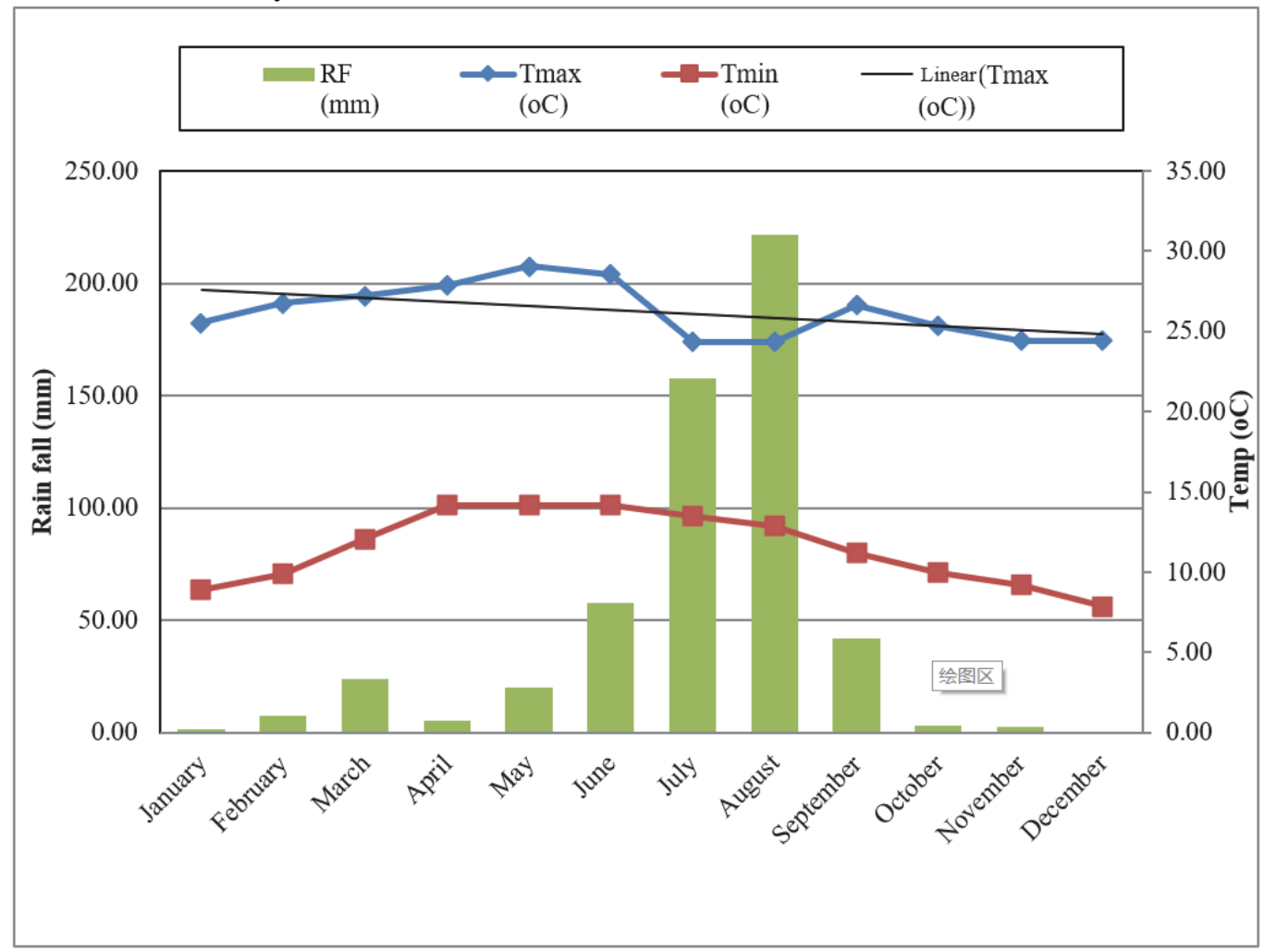

\section{Copyrights}

Copyright for this article is retained by the author(s), with first publication rights granted to the journal.

This is an open-access article distributed under the terms and conditions of the Creative Commons Attribution license (http://creativecommons.org/licenses/by/4.0/). 